\title{
Pseudonocardia acaciae sp. nov., isolated from roots of Acacia auriculiformis A. Cunn. ex Benth.
}

\author{
Correspondence \\ Kannika Duangmal \\ fscikkd@ku.ac.th \\ or \\ kannikaduangmal@hotmail.com
}

\author{
Kannika Duangmal, ${ }^{1}$ Arinthip Thamchaipenet, ${ }^{2}$ Atsuko Matsumoto ${ }^{3}$ \\ and Yoko Takahashi ${ }^{3}$ \\ ${ }^{1}$ Department of Microbiology, Faculty of Science, Kasetsart University, Chatuchak, Bangkok 10900, \\ Thailand \\ ${ }^{2}$ Department of Genetics, Faculty of Science, Kasetsart University, Chatuchak, Bangkok 10900, \\ Thailand \\ ${ }^{3}$ Kitasato Institute for Life Sciences, Kitasato University, 5-9-1 Shirokane, Minato-ku, Tokyo 108- \\ 8641, Japan
}

\begin{abstract}
A novel Gram-positive-staining actinomycete designated strain GMKU095 $^{\top}$ was isolated from surface-sterilized roots of Acacia auriculiformis A. Cunn. ex Benth. (earpod wattle). The organism produced branching mycelium. The spores were non-motile and had a spiny surface. Growth of strain GMKU095 ${ }^{\top}$ occurred at $18-42{ }^{\circ} \mathrm{C}, \mathrm{pH} 5.0-8.0$ and at $\mathrm{NaCl}$ concentrations up to $5 \%$. Whole-cell hydrolysates contained arabinose and galactose as major characteristic sugars. The diagnostic diamino acid of the peptidoglycan was meso-diaminopimelic acid. The glycan moiety of the murein contained acetyl residues. The menaquinone was $\mathrm{MK}-8\left(\mathrm{H}_{4}\right)$; mycolic acids were not detected. The $\mathrm{G}+\mathrm{C}$ content of the DNA was $71.6 \mathrm{~mol} \%$. iso- $\mathrm{C}_{16: 0}$ was detected as the major cellular fatty acid. Comparative studies of $16 \mathrm{~S}$ rRNA gene sequences indicated that the strain was phylogenetically related to members of the genus Pseudonocardia. The most closely related type strain is Pseudonocardia spinosispora IMSNU $50581^{\top}$, which is $96.2 \%$ similar in $16 \mathrm{~S}$ rRNA gene sequence. On the basis of the genotypic and phenotypic properties presented, a novel species of the genus Pseudonocardia is proposed, Pseudonocardia acaciae sp. nov. The type

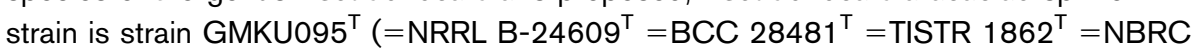
$104274^{\top}$ ).
\end{abstract}

The genus Pseudonocardia was proposed by Henssen (1957) and its description has been emended by Warwick et al. (1994), McVeigh et al. (1994), Reichert et al. (1998) and Huang et al. (2002). At the time of writing, the genus contains 27 species with validly published names. Strains have been isolated from a wide range of habitats such as treebark compost (Reichert et al., 1998), a gold mine (Lee et al., 2001), industrial sludge contaminated with 1,4-dioxane (Mahendra \& Alvarez-Cohen, 2005) and coastal sediment (Liu et al., 2006). The most recently reported species was Pseudonocardia oroxyli, which was isolated from surfacesterilized roots of the higher plant Oroxylum indicum $(\mathrm{Gu}$ et al., 2006). In this paper, a novel Pseudonocardia strain isolated from roots of Acacia auriculiformis A. Cunn. ex Benth. (earpod wattle) is described.

Strain GMKU095 ${ }^{\mathrm{T}}$ was isolated from surface-sterilized roots of Acacia auriculiformis A. Cunn. ex Benth. using starch-casein agar (Küster \& Williams, 1964) supplemented

Abbreviation: $\mathrm{A}_{2} \mathrm{pm}$, diaminopimelic acid.

The GenBank/EMBL/DDBJ accession number for the $16 \mathrm{~S}$ rRNA gene sequence of strain GMKU095' is EU921261. with antibacterial and antifungal agents (nalidixic acid and ketokonazole at 25 and $50 \mu \mathrm{g} \mathrm{ml}^{-1}$, respectively). The plates were incubated at $28{ }^{\circ} \mathrm{C}$ for 21 days. Small colonies with white spore mass were the predominant actinomycete colonies growing on the isolation plates. One of these colonies was isolated and purified on glucose-yeast extract agar (GYE agar) [containing $1.0 \%$ glucose, $1.0 \%$ yeast extract and $1.5 \%$ agar $(\mathrm{w} / \mathrm{v})]$. The pure culture was maintained as a $20 \%$ glycerol suspension at $-20{ }^{\circ} \mathrm{C}$ or as lyophilized cells for long-term preservation.

The morphological characteristics of strain GMKU095 ${ }^{\mathrm{T}}$ were observed by light microscopy and scanning electron microscopy (JEOL JSM 5600 LV) of 10-day-old cultures grown on ISP 3 medium (International Streptomyces Project; Shirling \& Gottlieb, 1966). Acid production from carbohydrates was determined using media and methods described by Gordon et al. (1974). Enzyme activity profiles were tested using API ZYM (bioMérieux), covering 19 enzyme activities. Urease activity was determined by a colour change in urea broth (Gordon et al., 1974). The temperature range for growth was determined on ISP 2 (Shirling \& Gottlieb, 1966) using a temperature gradient 
incubator (Tokyo Kagaku Sangyo) set with low and high temperatures of 5 and $50{ }^{\circ} \mathrm{C}$. Casein and gelatin hydrolysis and reduction of nitrate were evaluated using the methods of Gordon \& Mihm (1957). Production of melanoid pigment was determined by the method of the ISP (Shirling \& Gottlieb, 1966). NaCl tolerance was studied on ISP 2 containing $\mathrm{NaCl}$ at a final concentration of 1-9\% $(\mathrm{w} / \mathrm{v}) \cdot \mathrm{pH}$ tolerance was studied at $\mathrm{pH}$ 4-10.

Biomass for chemotaxonomic studies was obtained after growing strain GMKU095 ${ }^{\mathrm{T}}$ in GYE broth in shake flasks for 10 days at $28{ }^{\circ} \mathrm{C}$. The resultant cells were washed three times in distilled water and freeze-dried. Standard procedures were used to determine the isomer of diaminopimelic acid $\left(\mathrm{A}_{2} \mathrm{pm}\right)$ (Hasegawa et al., 1983). The acyl type of the cell wall was analysed according to the method of Uchida \& Aida (1984). Whole-cell sugars were analysed according to the method of Becker et al. (1965). Menaquinones were extracted and purified by the method of Collins et al. (1977), and isoprene units were analysed by HPLC using a JASCO 802-SC chromatograph equipped with a Shiseido CAPCELL PAK C18 column (Tamaoka et al., 1983). Mycolic acids were detected by TLC according to the method of Tomiyasu (1982). The G $+C$ content of the DNA, isolated following the method of Marmur (1961), was determined by HPLC according to the method of Tamaoka \& Komagata (1984). Analysis of fatty acids in cells grown on ISP 2 at $37^{\circ} \mathrm{C}$ for 10 days was performed according to the procedures of the Sherlock Microbial Identification System (Microbial ID).

The $16 \mathrm{~S}$ rRNA gene of strain GMKU095 ${ }^{\mathrm{T}}$ was amplified as described by Duangmal et al. (2005). The PCR products were purified and sequenced using an ABI PRISM BigDye Terminator v3.0 cycle sequencing ready reaction kit (Applied Biosystems) and universal primers (Lane, 1991). The almost-complete 16S rRNA gene sequence (1483 bp) was aligned with the corresponding sequences of representatives of the genus Pseudonocardia and related genera, retrieved from the GenBank database, using the CLUSTAL_X (Thompson et al., 1997) and PHYDIT (http://plaza.snu.ac.kr/ $\sim$ jchun/phydit/) programs.

Phylogenetic trees were inferred by using the least-squares (Fitch \& Margoliash, 1967), maximum-parsimony (Kluge \& Farris, 1969) and neighbour-joining (Saitou \& Nei, 1987) tree-making methods from the PHYLIP suite of programs (Felsenstein, 1993). The resultant tree topologies were evaluated by using bootstrap analyses (Felsenstein, 1985) based on 1000 resampled datasets using the SEQBOOT and CONSENSE options from the PHYLIP package. The resultant phylogenetic trees were viewed using the TreeView program (Page, 1996).

Strain GMKU095 ${ }^{\mathrm{T}}$ was a Gram-positive-staining, aerobic, filamentous actinobacterium with white to yellowish-white aerial mycelium and yellowish-brown substrate mycelium on ISP 2 agar after 10 days at $37^{\circ} \mathrm{C}$. Chains of oval spores with spiny surfaces were produced on ISP 2 agar (Fig. 1). Growth occurred in both standing and shake-flask cultures.

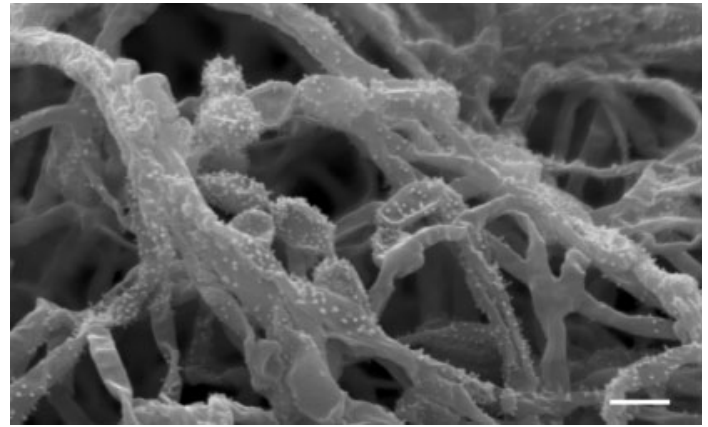

Fig. 1. Scanning electron micrograph of strain $\mathrm{GMKU095^{ \top }}$ grown for 10 days at $28^{\circ} \mathrm{C}$ on ISP 3 agar. Bar, $1 \mu \mathrm{m}$.

The results of chemical analysis indicated that the organism has chemotaxonomic markers typical of the genus Pseudonocardia (Huang et al., 2002). Strain GMKU095 ${ }^{\mathrm{T}}$ contained meso- $\mathrm{A}_{2} \mathrm{pm}$ in the peptidoglycan and MK-8 $\left(\mathrm{H}_{4}\right)$ as the major menaquinone. No mycolic acids were detected. The predominant cellular fatty acids were iso$\mathrm{C}_{16: 0}(23.13 \%)$, anteiso- $\mathrm{C}_{17: 0}(16.23 \%), 10$-methyl $\mathrm{C}_{16: 0}$ $(10.22 \%), \mathrm{C}_{17: 1} \omega 6 c(7.40 \%)$, iso- $\mathrm{C}_{17: 0}(7.10 \%), \quad 10-$ methyl $\mathrm{C}_{17: 0}(6.21 \%)$, iso- $\mathrm{C}_{15: 0}(5.66 \%)$ and $\mathrm{C}_{16: 0}$ $(5.57 \%)$. Fatty acids present as minor components are $\mathrm{C}_{17: 1} \omega 8 c(3.73 \%), \mathrm{C}_{17: 0}(2.00 \%)$, anteiso- $\mathrm{C}_{15: 0}(1.89 \%)$, $\mathrm{C}_{15: 0}(0.93 \%)$, iso- $\mathrm{C}_{16: 1} \mathrm{H}(0.85 \%)$, iso- $\mathrm{C}_{18: 0}(0.64 \%)$, $\mathrm{C}_{16: 1} \quad 2-\mathrm{OH} \quad(0.62 \%), \mathrm{C}_{18: 1} \omega 9 c \quad(0.52 \%)$, iso- $\mathrm{C}_{14: 0}$ $(0.40 \%)$ and $\mathrm{C}_{12: 0} 2-\mathrm{OH}(0.30 \%)$. The $\mathrm{G}+\mathrm{C}$ content of the DNA was $71.6 \mathrm{~mol} \%$. Phylogenetic analysis of an almost-complete $16 \mathrm{~S}$ rRNA gene sequence of strain GMKU095 ${ }^{\mathrm{T}}$ indicated that the isolate formed a distinct cluster with members of the genus Pseudonocardia (Fig. 2). The 16S rRNA gene sequence similarity between strain

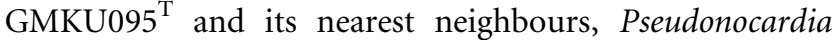
spinosispora LM $141^{\mathrm{T}}$ and Pseudonocardia asaccharolytica DSM $44247^{\mathrm{T}}$, was 96.2 and $96.0 \%$, respectively. The relatively low level of $16 \mathrm{~S}$ rRNA gene sequence similarity clearly differentiated strain GMKU095 ${ }^{\mathrm{T}}$ from its closest phylogenetic relatives. A $16 \mathrm{~S}$ rRNA gene sequence similarity of less than $97 \%$ generally indicates an overall genomic relatedness of less than $70 \%$, the cut-off point recommended for delineation of genomic species (Stackebrandt \& Goebel, 1994). Much higher 16S rRNA gene sequence similarities have been recorded between representatives of several Pseudonocardia species with validly published names that have DNA-DNA relatedness values well below the $70 \%$ cut-off point recommended by Wayne et al. (1987) for the circumscription of strains that belong to the same genomic species. The type strains of Pseudonocardia tetrahydrofuranoxydans and Pseudonocardia hydrocarbonoxydans, for example, share a $16 \mathrm{~S}$ rRNA gene sequence similarity of $99.3 \%$, but have a DNA-DNA relatedness of $31.7 \%$ (Kämpfer et al., 2006). Similarly, the type strain of Pseudonocardia kongjuensis shows $98.8 \%$ 16S rRNA gene sequence similarity to the 


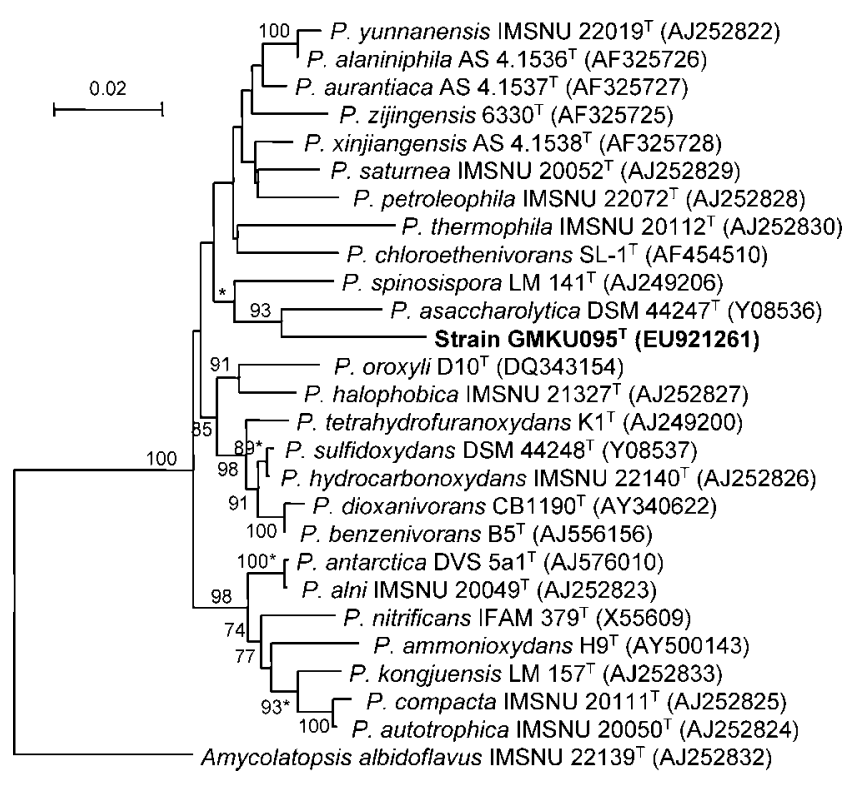

Fig. 2. Neighbour-joining tree derived from $16 \mathrm{~S}$ rRNA gene sequences showing the relationship of strain GMKU095 ${ }^{\top}$ with members of the genus Pseudonocardia. The tree was based on a comparison of 1323 nucleotide positions. Asterisks indicate branches of the tree that were also found using the least-squares (Fitch \& Margoliash, 1967) and maximum-parsimony (Kluge \& Farris, 1969) tree-making algorithms. Numbers at nodes indicate percentage bootstrap support from an analysis of 1000 resampled datasets. Bar, 0.02 substitutions per site.

type strain of its closest neighbour, Pseudonocardia autotrophica, but they share a DNA-DNA relatedness of only $32 \%$ (Lee et al., 2001).

Strain GMKU095 ${ }^{\mathrm{T}}$ was positive for catalase and urease activities. Observation of cultures over 14 days revealed growth in a temperature range of $18-42{ }^{\circ} \mathrm{C}$, with optimum growth at $36-38{ }^{\circ} \mathrm{C}$. No growth was observed at or above $44{ }^{\circ} \mathrm{C}$. The strain was able to grow at $\mathrm{pH} 5.0$ and 8.0, with optimal growth at $\mathrm{pH} 6.0-7.0 \mathrm{NaCl}$ was tolerated up to $5 \%$. Melanin pigment was not produced. Strain GMKU095 $^{\mathrm{T}}$ was readily differentiated from its closest relatives ( $P$. asaccharolytica DSM $44247^{\mathrm{T}}$ and P. spinosispora IMSNU $50581^{\mathrm{T}}$ ) on the basis of physiological properties (Table 1), especially the ability to produce acid from mannitol, the decomposition of tyrosine, hydrolysis of gelatin and starch, growth at $37{ }^{\circ} \mathrm{C}$ and growth with $3 \%$ $\mathrm{NaCl}$. Moreover, growth of strain GMKU095 ${ }^{\mathrm{T}}$ occurred between 18 and $42{ }^{\circ} \mathrm{C}$, whereas the growth of $P$. spinosispora IMSNU $50581^{\mathrm{T}}$ occurred at $4-30{ }^{\circ} \mathrm{C}$.

In conclusion, strain GMKU095 ${ }^{\mathrm{T}}$ is clearly differentiated from $P$. asaccharolytica DSM $44247^{\mathrm{T}}$ and P. spinosispora IMSNU $50581^{\mathrm{T}}$ based on polyphasic taxonomic analysis. We conclude that strain GMKU095 ${ }^{\mathrm{T}}$ represents a novel species of Pseudonocardia, for which the name Pseudonocardia acaciae sp. nov. is proposed.
Table 1. Differential characteristics of strain $G M K U 095^{\top}$ and closely related strains of the genus Pseudonocardia

Strains: 1, strain GMKU095 $; 2$, P. asaccharolytica DSM $44247^{\mathrm{T}} ; 3, P$. spinosispora IMSNU $50581^{\mathrm{T}}$. + , Positive; $\mathrm{W}$, weakly positive; -, negative; ND, no data. Data for reference strains were taken from Reichert et al. (1998) and Lee et al. (2002). All three strains have iso$\mathrm{C}_{16: 0}$ as the predominant fatty acid.

\begin{tabular}{|lccc|}
\hline Characteristic & $\mathbf{1}$ & $\mathbf{2}$ & $\mathbf{3}$ \\
\hline Spore surface & Spiny & Smooth & Spiny \\
Acid production from: & & & \\
$\quad$ Adonitol & + & - & + \\
$\quad$ L-Arabinose & + & - & + \\
$\quad$ D-Fructose & + & - & + \\
$\quad$ D-Glucose & + & - & + \\
myo-Inositol & W & - & + \\
Mannitol & W & - & - \\
L-Rhamnose & + & - & + \\
$\quad$ D-Xylose & + & - & + \\
$\mathrm{H}_{2} S$ production & - & - & + \\
Urease & + & - & + \\
Decomposition of tyrosine & + & - & - \\
Hydrolysis of: & & & \\
$\quad$ Gelatin & + & - & - \\
Starch & + & - & - \\
Growth temperature $\left({ }^{\circ} \mathrm{C}\right)$ & $18-42$ & ND & $4-30$ \\
Growth at $37{ }^{\circ} \mathrm{C}$ & + & - & - \\
Growth with $3 \% \mathrm{NaCl}$ & + & - & - \\
& & & \\
\hline
\end{tabular}

\section{Description of Pseudonocardia acaciae sp. nov.}

Pseudonocardia acaciae (a.ca.ci'ae. L. n. acacia the acacia tree and also the name of a botanical genus; L. gen. n. acaciae of Acacia, referring to the isolation of the type strain from roots of Acacia auriculiformis A. Cunn. ex Benth.).

Aerobic, Gram-positive-staining, non-acid-alcohol-fast. Forms yellowish-white aerial mycelium and yellowishbrown substrate mycelium on ISP 2 agar. The spiny spores occur in chains. Growth occurs in both standing and shake-flask cultures. Catalase, nitrate reduction and urease are positive. $\mathrm{H}_{2} \mathrm{~S}$ is not produced. Acid is produced from adonitol, L-arabinose, D-fructose, D-glucose, D-mannose, Lrhamnose, ribose and D-xylose. No acid production from D-galactose, lactose, maltose, melezitose, raffinose, Dsorbitol or sucrose. Weak acid production from glycerol, myo-inositol and mannitol. Hydrolyses gelatin and starch, but not casein. Growth occurs at $\mathrm{pH} 5.0-8.0$, with an optimum at $\mathrm{pH}$ 6.0-7.0. The temperature range for growth is $18-42{ }^{\circ} \mathrm{C}$, with an optimum at $36-38{ }^{\circ} \mathrm{C}$. On ISP 2 agar, good growth occurs at $0-1 \% \mathrm{NaCl}$, moderate growth at $2 \% \mathrm{NaCl}$ and poor growth at 3-5\% NaCl. Esterase (C4), lipase (C8), leucine aminopeptidase and valine aminopeptidase are detected with the API ZYM enzyme assay; acid and alkaline phosphatases, $\alpha$-galactosidase, $\beta$-galactosidase, $\alpha$-glucosidase, $\beta$-glucosidase, trypsin, phosphoamidase, chymotrypsin, cystine aminopeptidase, $\alpha$-fucosidase, $\beta$ - 
glucuronidase, lipase (C14), $\alpha$-mannosidase and $N$-acetyl$\beta$-glucosaminidase are not detected. The diagnostic diamino acid of the peptidoglycan is meso- $\mathrm{A}_{2} \mathrm{pm}$. Wholecell sugars are arabinose and galactose. The glycan moiety of the murein is acetylated. The predominant menaquinone is MK- $8\left(\mathrm{H}_{4}\right)$. Mycolic acids are not detected. The fatty acid profile is dominated by iso- $\mathrm{C}_{16: 0}$, anteiso- $\mathrm{C}_{17: 0}$, 10-methyl $\mathrm{C}_{16: 0}, \mathrm{C}_{17: 1} \omega 6 c$, iso- $\mathrm{C}_{17: 0}, 10$-methyl $\mathrm{C}_{17: 0}$, iso$\mathrm{C}_{15: 0}$ and $\mathrm{C}_{16: 0}$. Other cellular fatty acids detected as minor components $(<5 \%)$ are $\mathrm{C}_{17: 1} \omega 8 c, \mathrm{C}_{17: 0}$, anteiso$\mathrm{C}_{15: 0}, \mathrm{C}_{15: 0}$, iso- $\mathrm{C}_{16: 1} \mathrm{H}$, iso- $\mathrm{C}_{18: 0}, \mathrm{C}_{16: 1} 2-\mathrm{OH}, \mathrm{C}_{18: 1} \omega 9 c$, iso- $\mathrm{C}_{14: 0}$ and $\mathrm{C}_{12: 0} 2-\mathrm{OH}$. The $\mathrm{G}+\mathrm{C}$ content of the DNA of the type strain is $71.6 \mathrm{~mol} \%$.

The type strain, strain GMKU095 ${ }^{\mathrm{T}}\left(=\mathrm{NRRL}\right.$ B- $24609^{\mathrm{T}}$ $=$ BCC $28481^{\mathrm{T}}=$ TISTR $1862^{\mathrm{T}}=$ NBRC $\left.104274^{\mathrm{T}}\right)$, was isolated from roots of Acacia auriculiformis A. Cunn. ex Benth., collected from Kasetsart University, Bangkok, Thailand.

\section{Acknowledgements}

This study was supported by the Commission on Higher Education and the Thailand Research Fund, Kasetsart University Research and Development Institute and Faculty of Science, Kasetsart University.

\section{References}

Becker, B., Lechevalier, M. P. \& Lechevalier, H. A. (1965). Chemical composition of cell-wall preparations from strains of various formgenera of aerobic actinomycetes. Appl Microbiol 13, 236-243.

Collins, M. D., Pirouz, T., Goodfellow, M. \& Minnikin, D. E. (1977). Distribution of menaquinones in actinomycetes and corynebacteria. J Gen Microbiol 100, 221-230.

Duangmal, K., Ward, A. C. \& Goodfellow, M. (2005). Selective isolation of members of the Streptomyces violaceoruber clade from soil. FEMS Microbiol Lett 245, 321-327.

Felsenstein, J. (1985). Confidence limits on phylogenies: an approach using the bootstrap. Evolution 39, 783-791.

Felsenstein, J. (1993). PHYLIP (phylogeny inference package), version 3.5c. Distributed by the author. Department of Genome Sciences, University of Washington, Seattle, USA.

Fitch, W. M. \& Margoliash, E. (1967). Construction of phylogenetic trees: a method based on mutation distances as estimated from cytochrome $c$ sequences is of general applicability. Science 155, 279284.

Gordon, R. E. \& Mihm, J. M. (1957). A comparative study of some strains received as nocardiae. J Bacteriol 73, 15-27.

Gordon, R. E., Barnett, D. A., Handerhan, J. E. \& Pang, C. H.-N. (1974). Nocardia coeliaca, Nocardia autotrophica, and the nocardin strain. Int J Syst Bacteriol 24, 54-63.

Gu, Q., Luo, H., Zheng, W., Liu, Z. \& Huang, Y. (2006). Pseudonocardia oroxyli sp. nov., a novel actinomycete isolated from surface-sterilized Oroxylum indicum root. Int J Syst Evol Microbiol 56, 2193-2197.

Hasegawa, T., Takizawa, M. \& Tanida, S. (1983). A rapid analysis for chemical grouping of aerobic actinomycetes. J Gen Appl Microbiol 29, 319-322.

Henssen, A. (1957). Beiträge zur Morphologie und Systematik der thermophilen Actinomyceten. Arch Mikrobiol 26, 373-414 (in German).
Huang, Y., Wang, L., Lu, Z., Hong, L., Liu, Z., Tan, G. Y. A. \& Goodfellow, M. (2002). Proposal to combine the genera Actinobispora and Pseudonocardia in an emended genus Pseudonocardia, and description of Pseudonocardia zijingensis sp. nov. Int J Syst Evol Microbiol 52, 977-982.

Kämpfer, P., Kohlweyer, U., Thiemer, B. \& Andreesen, J. R. (2006). Pseudonocardia tetrahydrofuranoxydans sp. nov. Int $J$ Syst Evol Microbiol 56, 1535-1538.

Kluge, A. G. \& Farris, J. S. (1969). Quantitative phyletics and the evolution of anurans. Syst Zool 18, 1-32.

Küster, E. \& Williams, S. T. (1964). Media for the isolation of streptomycetes: starch casein medium. Nature 202, 928-929.

Lane, D. J. (1991). 16S/23S rRNA sequencing. In Nucleic Acid Techniques in Bacterial Systematics, pp. 115-175. Edited by E. Stackebrandt \& M. Goodfellow. Chichester: Wiley.

Lee, S. D., Kim, E. S., Min, K. L., Lee, W. Y., Kang, S. O. \& Hah, Y. C. (2001). Pseudonocardia kongjuensis sp. nov., isolated from a gold mine cave. Int J Syst Evol Microbiol 51, 1505-1510.

Lee, S. D., Kim, E. S., Kang, S. O. \& Hah, Y. C. (2002). Pseudonocardia spinosispora sp. nov., isolated from Korean soil. Int J Syst Evol Microbiol 52, 1603-1608.

Liu, Z. P., Wu, J. F., Liu, Z. H. \& Liu, S. J. (2006). Pseudonocardia ammonioxydans sp. nov., isolated from coastal sediment. Int J Syst Evol Microbiol 56, 555-558.

Mahendra, S. \& Alvarez-Cohen, L. (2005). Pseudonocardia dioxanivorans sp. nov., a novel actinomycete that grows on 1,4-dioxane. Int J Syst Evol Microbiol 55, 593-598.

Marmur, J. (1961). A procedure for the isolation of deoxyribonucleic acid from microorganisms. J Mol Biol 3, 208-218.

McVeigh, H. P., Munro, J. \& Embley, T. M. (1994). The phylogenetic position of Pseudoamycolata halophobica (Akimov et al. 1989) and a proposal to reclassify it as Pseudonocardia halophobica. Int J Syst Bacteriol 44, 300-302.

Page, R. D. M. (1996). TreeView: an application to display phylogenetic trees on personal computers. Comput Appl Biosci 12, 357-358.

Reichert, K., Lipski, A., Pradella, S., Stackebrandt, E. \& Altendorf, K. (1998). Pseudonocardia asaccharolytica sp. nov. and Pseudonocardia sulfidoxydans sp. nov., two new dimethyl disulfide-degrading actinomycetes and emended description of the genus Pseudonocardia. Int J Syst Bacteriol 48, 441-449.

Saitou, N. \& Nei, M. (1987). The neighbor-joining method: a new method for reconstructing phylogenetic trees. Mol Biol Evol 4, 406425.

Shirling, E. B. \& Gottlieb, D. (1966). Methods for characterization of Streptomyces species. Int J Syst Bacteriol 16, 313-340.

Stackebrandt, E. \& Goebel, B. M. (1994). Taxonomic note: a place for DNA-DNA reassociation and $16 \mathrm{~S}$ rRNA sequence analysis in the present species definition in bacteriology. Int J Syst Bacteriol 44, 846849.

Tamaoka, J. \& Komagata, K. (1984). Determination of DNA base composition by reversed-phase high-performance liquid chromatography. FEMS Microbiol Lett 25, 125-128.

Tamaoka, J., Katayara-Fujimura, Y. \& Kuraishi, H. (1983). Analysis of bacterial menaquinone mixtures by high performance liquid chromatography. J Appl Bacteriol 54, 31-36.

Thompson, J. D., Gibson, T. J., Plewniak, F., Jeanmougin, F. \& Higgins, D. G. (1997). The CLUSTAL_X windows interface: flexible strategies for multiple sequence alignment aided by quality analysis tools. Nucleic Acids Res 25, 4876-4882. 
Tomiyasu, I. (1982). Mycolic acid composition and thermally adaptative changes in Nocardia asteroides. J Bacteriol 151, 828-837.

Uchida, K. \& Aida, K. (1984). An improved method for the glycolate test for simple identification of acyl type of bacterial cell walls. J Gen Appl Microbiol 30, 131-134.

Warwick, S., Bowen, T., McVeigh, H. P. \& Embley, T. M. (1994). A phylogenetic analysis of the family Pseudonocardiaceae and the genera Actinokineospora and Saccharothrix with 16S rRNA sequences and a proposal to combine the genera Amycolata and Pseudonocardia in an emended genus Pseudonocardia. Int J Syst Bacteriol 44, 293-299.

Wayne, L. G., Brenner, D. J., Colwell, R. R., Grimont, P. A. D., Kandler, O., Krichevsky, M. I., Moore, L. H., Moore, W. E. C., Murray,

R. G. E. \& other authors (1987). International Committee on Systematic Bacteriology. Report of the ad hoc committee on reconciliation of approaches to bacterial systematics. Int $J$ Syst Bacteriol 37, 463-464. 